\title{
C-reactive protein predicts complications in community-associated S. aureus bacteraemia: a cohort study
}

\author{
Carly L. Botheras ${ }^{1,2^{*}}$ (D, Steven J. Bowe ${ }^{3}$, Raquel Cowan $^{4}$ and Eugene Athan ${ }^{1,2,4}$
}

\begin{abstract}
Background: Staphylococcus aureus (S. aureus) bacteraemia is increasingly acquired from community settings and is associated with a mortality rate of up to $40 \%$ following complications. Identifying risk factors for complicated $\mathbf{S}$. aureus bacteraemia would aid clinicians in targeting patients that benefit from expedited investigations and escalated care.

Methods: In this prospective observational cohort study, we aimed to identify risk factors associated with a complicated infection in community-onset $S$. aureus bacteraemia. Potential risk factors were collected from electronic medical records and included: - patient demographics, symptomology, portal of entry, and laboratory results.

Results: We identified several potential risk factors using univariate analysis. In a multiple logistic regression model, age, haemodialysis, and entry point from a diabetic foot ulcer were all significantly protective against complications. Conversely, an unknown entry point of infection, an entry point from an indwelling medical device, and a Creactive protein concentration of over $161 \mathrm{mg} / \mathrm{L}$ on the day of admission were all significantly associated with complications.

Conclusions: We conclude that several factors are associated with complications including already conducted laboratory investigations and portal of entry of infection. These factors could aid the triage of at-risk patients for complications of $\mathrm{S}$. aureus bacteraemia.
\end{abstract}

Keywords: S. aureus bacteraemia, Complications, Epidemiology, C-reactive protein

\section{Background}

S. aureus is a Gram-positive bacterium that can cause many diseases including bacteraemia. Cases of S. aureus bacteraemia $[\mathrm{SAB}]$ are common and incidence rates remain stable $[1,2]$. In Australia, SAB occurs at an annual rate of 10 per 100,000 people [3] and is mostly acquired from the community [4]. Risk of mortality remains high

\footnotetext{
* Correspondence: cbothera@deakin.edu.au

${ }^{1}$ School of Medicine, IMPACT, the Institute for Mental and Physical Health and Clinical Translation, Deakin University, Geelong, Australia

${ }^{2}$ School of Medicine, Faculty of Health, Deakin University, Geelong, Australia Full list of author information is available at the end of the article
}

with international data suggesting rates of up to 40\% [5] with Australian mortality currently reported at $18.3 \%$ [3]. Complications of SAB are common and include infective endocarditis, osteomyelitis, and severe sepsis. These complications are responsible for the need of greater interventions, longer admissions to hospital and increased risk of mortality.

Several studies have aimed to identify specific factors that may aid clinicians in identifying complications in $\mathrm{SAB}$ [6-8]. There is debate on gender, age and co-morbidity burden, with increased incidence of infection noted, but polarising results on outcome [9-11]. The

C C The Author(s). 2021 Open Access This article is licensed under a Creative Commons Attribution 4.0 International License, which permits use, sharing, adaptation, distribution and reproduction in any medium or format, as long as you give appropriate credit to the original author(s) and the source, provide a link to the Creative Commons licence, and indicate if changes were made. The images or other third party material in this article are included in the article's Creative Commons licence, unless indicated otherwise in a credit line to the material. If material is not included in the article's Creative Commons licence and your intended use is not permitted by statutory regulation or exceeds the permitted use, you will need to obtain permission directly from the copyright holder. To view a copy of this licence, visit http://creativecommons.org/licenses/by/4.0/ The Creative Commons Public Domain Dedication waiver (http://creativecommons.org/publicdomain/zero/1.0/) applies to the data made available in this article, unless otherwise stated in a credit line to the data. 
antibiotic resistance profile of $S$. aureus [12], whether it persists with treatment [13], and where it is acquired are also possible risk factors for complications [11].

Predictive biomarkers have also been studied. C-reactive protein $[\mathrm{CRP}]$ is an acute phase reactant released from the liver and is raised in response to tissue injury and metabolic stressors. Several conditions that increase CRP have been observed including inflammatory processes, cancer, pregnancy and infection [14-16].

Although CRP has been rejected as a diagnostic marker for SAB due to the lack of specificity [17], it has also been investigated as a predictive factor of SAB complications. There are limitations to extrapolating these results to a clinical setting. Firstly, international studies on SAB often include healthcare-acquired infections and do not accurately reflect the increasingly common community-associated setting [18]. Other studies do not focus solely upon $S$. aureus, limiting the translation of the findings [19]. It is important to identify factors, including CRP, that are associated with an increased risk of complicated SAB acquired from the community. This is to better inform management guidelines and impact on mortality rates.

In this study, we aimed to identify potential predicting factors for complication of community-associated SAB infections from all adult cases of SAB that presented to a single institution in Australia. We ascertained several factors that could predict complications and suggest that CRP may be a very useful and readily available biomarker.

\section{Methods}

\section{Sample selection}

University Hospital Geelong [UHG] is a 500-bed tertiary referral hospital in the south-west of Victoria, Australia.
It has a catchment of a population of 600,000 and has a specialised Infectious Diseases service. From June 2015 to September 2018, 236 adult cases of SAB were prospectively identified at UHG. All adult cases admitted to the UHG with an initial positive blood culture of $S$. aureus flagged within $48 \mathrm{~h}$ of admission to hospital were included into the study (Fig. 1). Paediatric cases, culture negative cases, or a blood culture positive after $48 \mathrm{~h}$ of admission to hospital [healthcare-acquired] were excluded. Cases not admitted to UHG or transferred to another hospital before a complication was diagnosed were also excluded.

\section{Categorisation}

Cases included into the study were categorised on whether they were an uncomplicated or complicated. Categorisation were based upon definitions from the Infectious Disease Society of America Definition [20]. This defines uncomplicated $\mathrm{SAB}$ as a SAB which has no infective endocarditis or metastatic infection, no presence of an indwelling medical device within the patient, defervescence within $72 \mathrm{~h}$ of antibiotic commencement and no positive blood cultures after $72 \mathrm{~h}$ following commencement of antibiotics. Complicated SAB was classified as cases of SAB which did not match the uncomplicated definition.

\section{Data collection}

Cases were prospectively identified through the microbiology service (Australian Clinical Laboratories) and clinical data was collected from electronic medical records [EMR]. Data collected included patient demographics, symptomology and portal of entry, microbiological details, and biomarker and blood cell counts from the day of admission. These variables were selected as routinely

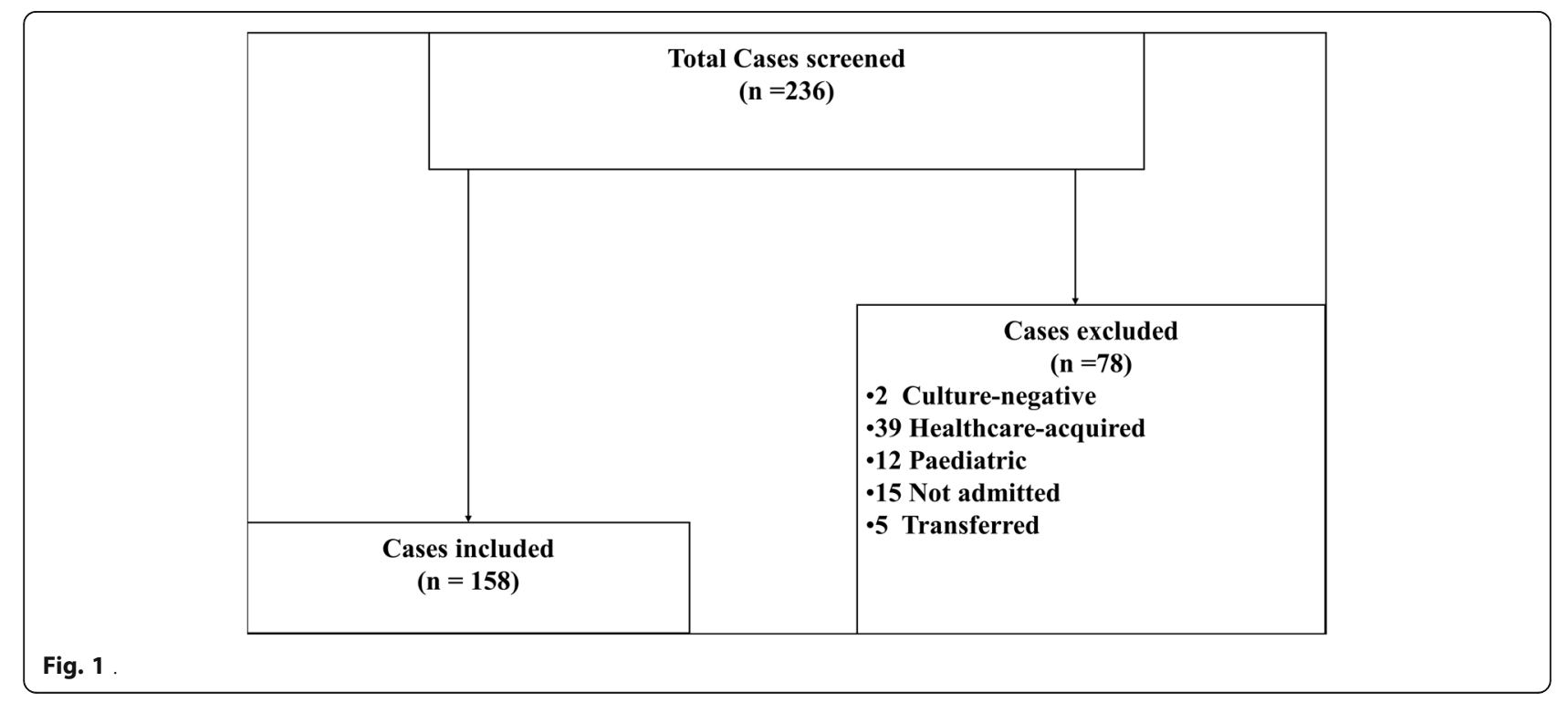


collected data and their potential as predictive variables for SAB complications. These factors are further detailed below.

\section{Demographics}

Demographics included age, gender and co-morbidities. Co-morbidity burden was determined through the Charlson age co-morbidity index [CACI] [21]. The CACI considers age, HIV status, renal and liver function, diabetic status, and peripheral vascular conditions as well as other conditions [21]. Other co-morbidities not used in the CACI, such as injecting drug use, immunosuppressive status, skin conditions and haemodialysis were also collected, as these co-morbidities are frequently associated with $S$. aureus infections [22-26].

\section{Symptomology and portal of entry}

Symptoms were described on admission and recorded in the EMR by the admitting medical officer. These included fever, rigors, nausea, lethargy, and pain. Pain included both local and generalised pain.

Portal of entry was defined as previously described from Smit et al. [27] with a few modifications. Briefly Smit et al. lists skin and soft tissue infection [SSTI], indwelling medical device associated [IMD], injecting drug use inoculation [IDU], other injections, other entry points, or unknown [27]. We did not include other injections and other entry points as we only had two other entry points observed and no other injections were observed. We instead included community-acquired pneumonia and separated diabetic foot ulcer from SSTI due to the potential increases risk of poor outcomes from these entry points $[5,28,29]$. SSTIs included pressure ulcers, non-diabetic foot ulcers, cellulitis, and other infections of the skin and soft tissue such as abscesses and boils. Pneumonia was defined as community-acquired pneumonia where there were no other entrance points of infection. IMD included catheters and recent implanted devices. IDU was defined as a SAB infection directly attributable to injecting drug use. An unknown entry point was defined as a case that didn't have any defined entry point.

\section{Laboratory test factors}

Microbiological data included whether the bacteraemia was persistent, as defined as having three or more days of consecutive positive blood cultures. The antibiotic sensitivity of the organism was determined through the VITEK 2 system [Biomerieux] and cefoxitin discs and were classified via definitions used by the pathology services. Those pan-sensitive were designated as penicillinsensitive [PSSA], isolates resistant to penicillin were classified as methicillin-sensitive [MSSA], those resistant toward cefoxitin but no other classes were classified as non-multi resistant [nm-MRSA] and those resistant to cefoxitin and other antibiotic classes were classified as methicillin-resistant [MRSA]. It was also noted if the $\mathrm{SAB}$ was part of a poly-microbial infection.

Biomarkers and blood tests were ordered at the discretion of the clinical team in charge of the patient on the day of admission. Results of available biomarkers and bloods were collected and included CRP concentration, platelet, leukocyte, neutrophil and lymphocyte cell counts. If a biomarker was collected more than once, the most divergent from the healthy range was chosen.

\section{Statistical analysis \\ Data presentation}

The outcome for the study was considered as a binary variable: Complicated infections (Yes/No).The explanatory/predictor variables of interest are both continuous and categorical variables. These include demographics, self-reported symptomology, portal of entry and microbiological and laboratory assessment variables. All categorical data are presented as \% [n], and non-normal continuous data are presented as medians and interquartile ranges $[\mathrm{IQR}]$.

\section{Univariate analysis- stage 1}

Pearson's Chi squared and Fisher's Exact tests and univariable logistic regression were used to determine whether there were associations between the outcome: complicated infections (Yes/No) and potential categorical predictor/exploratory variables. Whereas univariable logistic regression was used to explore potential associations between complicated infections (Yes/No) and continuous exploratory variables. Only results from the univariable logistic regressions are presented.

\section{Receiver operating characteristic (ROC) curve analysis- stage 2}

Significant blood markers determined from univariate analysis were also assessed for a potential cut-off value. The main blood marker of interest was CRP concentration. To determine a potential optimal cut-off values, Receiver Operating Characteristic (ROC) curve analysis was used and a cut-off value was predicted using the Youden Index.

\section{Multiple logistic regression- stage 3}

Exploratory variables were included in the multiple logistic regression modelling, if preliminary tests had a Wald statistic $p$-value $<0.2$. A stepwise forward and backward elimination approach was used to model certain potential predictors while variables deemed as potential confounders by the literature were included to adjust other associations the multiple logistic regression model. Post estimation analysis such as Hosmer- 
Lemeshow goodness of fit test, percentage or correctly classified and area under the curve were used to assess the appropriateness of the model. Only patients with complete data were included in the logistic regression modelling. For this exploratory analysis, a level of significance $(\alpha)$ of 5 and $95 \%$ confidence intervals were considered appropriate and reported. Although in the discussion of the final adjusted logistic regression model, a more conservative alpha level of 0.01 has been considered. All data were analysed using both Stata SE version 15.1 [30] and SPSS version 24.0 [31].

\section{Results}

\section{Description of the cohort}

From 2015 until 2018, 236 cases of SAB presented to UHG. After applying exclusion criteria, 158 cases of SAB were included into the study (Fig. 1). Complicated SAB represented $67.6 \%(n=107)$ cases of the study and $32.4 \%$ $(n=51)$ were categorised as uncomplicated.

\section{Demographics}

The median age was 68.5 years old (IQR: 29), CACI scores were a median of 5 (IQR: 6) and females represented $39.2 \%$ of the cohort. There were no significant associations of CACI score or gender with presentation. Intravenous drug use was low $(9.5 \%, n=15)$ in the cohort. As summarised in Table 1, age was associated with complications (OR: 1.03, 95\% CI: [1.01, 1.05], $p=0.003$ ) and haemodialysis was inversely associated with complications (OR: 0.07, 95\% CI: [0.01, 0.61], $p=0.016$ ).

\section{Self-reported symptomology}

Self-reported symptomology on admission is summarised in Table 2. Pain was the most common reported symptom $(65.8 \%, n=104)$, followed by fever (57.6\%, $n=91)$. Lethargy was the least common reported symptom $(19.6 \% n=31)$. Reporting rigors was inversely associated with complications (OR: 0.49, 95\% CI: [0.24, 0.99], $p=0.046$ ).

\section{Portal of entry}

An unknown entry point of infection was most common, representing $36.1 \%(n=57)$ of the cohort (Table 3$)$ and was strongly associated with complications (OR: 4.54, 95\% CI: $[1.95,10.57], p<0.001)$. Conversely, entry points from SSTIs (OR: $0.35,95 \% \mathrm{CI}$ : [0.17, 0.71$], p=0.003$ ) or DFUs (OR: 0.16, 95\% CI: [0.05, 0.54], $\mathrm{p}=0.003$ ) were inversely associated with complications.

\section{Microbiological and laboratory assessment}

As summarised in Table 4, most $S$. aureus isolates were methicillin sensitive $(74.1 \%, n=117)$. The prevalence of antibiotic resistant $S$. aureus was low within the study $(2.5 \%$ MRSA $(n=4), 5.1 \%$ nm-MRSA $(n=8))$ and was not associated with complicated SAB $(p=0.754$ for MRSA and $p=0.746$ for nm-MRSA). While polymicrobial $S$. aureus bacteraemia was inversely associated with complications, it was not statistically significant (OR: 0.38, 95\% CI: [0.14, 1.04], $p=0.061$ ).

Data on blood biomarkers and from full blood examinations collected on the day of admission were analysed and compared (Table 4). Univariable logistic regressions suggested significant associations between complications and the continuous variable of CRP, white blood cell count, and neutrophil cell count. Potentially important cut-off values were determined for each of these variables using Youden's Index and used in further analyses.

As shown in Table 4, it was observed that the presence of a CRP concentration over $161 \mathrm{mg} / \mathrm{L}$ was associated with complications (OR: 3.29, 95\% CI: [1.50, 7.24], $p=$ $0.003)$. In addition, a white cell count over $14.85 \times 10^{9}$ cells/L (OR: 3.09, 95\% CI:[1.31, 7.29], $p=0.01$ ) or a

Table 1 Demographic comparison between uncomplicated and complicated SAB

\begin{tabular}{|c|c|c|c|c|c|c|}
\hline \multirow[t]{2}{*}{ Demographic } & \multirow{2}{*}{$\begin{array}{l}\text { Total } \\
\%[n=158]\end{array}$} & \multirow{2}{*}{$\begin{array}{l}\text { Uncomplicated } \\
\%[n=51]\end{array}$} & \multirow{2}{*}{$\begin{array}{l}\text { Complicated } \\
\%[n=107]\end{array}$} & \multicolumn{3}{|c|}{ Comparison $^{a}$} \\
\hline & & & & Crude OR & $95 \% \mathrm{Cl}$ & $p$-value \\
\hline Age median (IQR) & $68.5(29.0)$ & $59.0(29.0)$ & $72.0(26.0)$ & 1.03 & $(1.01,1.05)$ & 0.003 \\
\hline \multicolumn{7}{|l|}{ Gender } \\
\hline Female & $39.2[62]$ & $41.2[21]$ & $38.3[41]$ & 0.89 & $(0.45,1.75)$ & 0.731 \\
\hline Male & $60.8[96]$ & $58.8[30]$ & $61.7[66]$ & & & \\
\hline CACI median (IQR) & $5.0(6.0)$ & $5.0(6.0)$ & $5.0(6.0)$ & 1.03 & $(0.93,1.13)$ & 0.597 \\
\hline Immunosuppression & $13.2[21]$ & $17.6[9]$ & $11.2[12]$ & 0.59 & $(0.23,1.51)$ & 0.269 \\
\hline Diabetes & $32.3[51]$ & $37.3[19]$ & 29.9 [32] & 0.72 & $(0.36,1.45)$ & 0.357 \\
\hline Injecting Drug User & $9.5[15]$ & $13.7[7]$ & $7.5[8]$ & 0.51 & $(0.17,1.49)$ & 0.217 \\
\hline Skin conditions ${ }^{b}$ & $3.8[6]$ & $7.8[4]$ & 1.9 [2] & 0.22 & $(0.04,1.27)$ & 0.090 \\
\hline Haemodialysis & 4.4 [7] & 11.8 [6] & 0.9 [1] & 0.07 & $(0.01,0.60)$ & 0.016 \\
\hline
\end{tabular}

CACl Charlson age co-morbidity index; OR Odds ratio; $C$ confidence interval

anivariable logistic regression model

${ }^{b}$ Eczema and atopic dermatitis 
Table 2 Symptomology comparison between uncomplicated and complicated SAB

\begin{tabular}{|c|c|c|c|c|c|c|}
\hline \multirow[t]{2}{*}{ Symptoms } & \multirow{2}{*}{$\begin{array}{l}\text { Total } \\
\%[n=158]\end{array}$} & \multirow{2}{*}{$\begin{array}{l}\text { Uncomplicated } \\
\%[n=51]\end{array}$} & \multirow{2}{*}{$\begin{array}{l}\text { Complicated } \\
\%[n=107]\end{array}$} & \multicolumn{3}{|c|}{ Comparison $^{a}$} \\
\hline & & & & Crude OR & $95 \% \mathrm{Cl}$ & $p$-value \\
\hline Fever & 57.6 [91] & $58.8[30]$ & $57.0[61]$ & 0.93 & $(0.47,1.83)$ & 0.829 \\
\hline Rigors & $32.2[51]$ & $43.1[22]$ & $27.1[29]$ & 0.49 & $(0.24,0.99)$ & 0.046 \\
\hline Nausea & $38.0[60]$ & $47.1[24]$ & 33.6 [36] & 0.57 & $(0.29,1.13)$ & 0.106 \\
\hline Lethargy & 19.6 [31] & 19.6 [10] & 19.6 [21] & 1.00 & $(0.43,2.32)$ & 0.998 \\
\hline Pain ${ }^{b}$ & 65.8 [104] & $52.7[32]$ & $67.3[72]$ & 1.22 & $(0.61,2.45)$ & 0.574 \\
\hline
\end{tabular}

OR Odds ratio; $C$ C Confidence Interval

a Univariable logistic regression model

${ }^{\mathrm{b}}$ Local and generalised pain

neutrophil cell count over $9.25 \times 10^{9}$ cells/L (OR: 2.06, 95\% CI:[1.02, 4.15], $p=0.043)$ were also associated with complications.

\section{Multiple logistic regression analysis}

The goodness of fit test suggested that the final multiple logistic regression model shown in Table 5 was a reasonably fitting model $(p=0.744)$. When all other independent variables were held constant in the model, CRP concentration over $161 \mathrm{mg} / \mathrm{L}$ on the day of admission was significantly associated with complications (adjusted odds ratio $\left(\mathrm{OR}_{\mathrm{adj}}\right)$ : 3.56; 95\% CI: [1.22, 10.40], $\left.p=0.020\right)$. Age (OR ${ }_{\text {adj: }}: 1.03,95 \% \mathrm{CI}$ : $\left.[1.01,1.06], p=0.014\right)$, an unknown entry point $\left(\mathrm{OR}_{\mathrm{adj}}\right.$ : 3.94, 95\% CI: [1.33, 11.62], $p=0.013)$ and a entry point from an IMD (OR adj:4.58, 95\% CI: $[1.14,18.35], p=0.032$ ) were also significantly associated with complications. Conversely, haemodialysis $\left(\mathrm{OR}_{\mathrm{adj}}\right.$ : $\left.0.09,95 \% \mathrm{CI}:[0.01,0.71], p=0.023\right)$ and an entry point from a DFU (OR $\mathrm{Odj}_{\mathrm{ad}}$ : 0.12, 95\% CI: [0.02, 0.77], $p=$ 0.025 ) were inversely associated with complicated disease.

\section{Discussion}

Current reported global mortality rates of SAB range between 10 and $35 \%[3,5,32,33]$ and are related to complications of the infection. Identifying complications earlier may improve implementation of appropriate therapy, identify the need for additional interventions and reduce this mortality rate [34]. To that end, several attempts to identify risk factors for complications have been attempted [35-38]. These studies are varied in definitions, methodology and populations. They also often focus upon one specific complication. Predictive models have also been attempted [39-42], but focus upon predicting mortality, a specific complication, or are hospital-acquired infections and thus may not be generalizable to the increasingly prevalent communityacquired setting of infection.

To our knowledge, no study has focussed specifically upon community-associated SAB; the predominant cause in Australia. In this study, we aimed to identify risk factors for complications from demographics, self-reported symptoms, portal of entry, and microbiological profile of the bacteria and from routine biomarkers in SAB.

Complicated SAB represented $67.6 \%$ of the cohort, with the median age of the cohort 68.5 years (IQR:29.0). Age was significantly associated with complications and this is also reflected in other studies [5, 32, 36, 43].

Haemodialysis (OR adj: 0.09, 95\% CI: [0.01, 0.71], $p=$ 0.023 ) was significantly inversely associated with complications in SAB. This may be due to the increased medical attention received by those who are on haemodialysis. It may be also be due to the portal of entry from an infected line, with early removal associated with improved

Table 3 Portal of entry compared between uncomplicated and complicated SAB

\begin{tabular}{|c|c|c|c|c|c|c|}
\hline \multirow[t]{2}{*}{ Portal of entry variables } & \multirow{2}{*}{$\begin{array}{l}\text { Total } \\
\%[n=158]\end{array}$} & \multirow{2}{*}{$\begin{array}{l}\text { Uncomplicated } \\
\%[n=51]\end{array}$} & \multirow{2}{*}{$\begin{array}{l}\text { Complicated } \\
\%[n=107]\end{array}$} & \multicolumn{3}{|c|}{ Comparison $^{a}$} \\
\hline & & & & Crude OR & $95 \% \mathrm{Cl}$ & $p$-value \\
\hline Skin/soft tissue infections & $32.9[52]$ & $49.0[25]$ & $25.2[27]$ & 0.35 & $(0.17,0.71)$ & 0.003 \\
\hline Diabetic foot ulcer & $8.9[14]$ & $8.9[10]$ & $3.7[4]$ & 0.16 & $(0.05,0.54)$ & 0.003 \\
\hline Pneumonia & $2.5[4]$ & $2.0[1]$ & $2.8[3]$ & 1.44 & $(0.15,14.22)$ & 0.754 \\
\hline Unknown & $36.1[57]$ & $15.7[8]$ & $45.8[49]$ & 4.54 & $(1.95,10.57)$ & $<0.001$ \\
\hline Indwelling medical devices ${ }^{b}$ & $15.8[25]$ & $9.8[5]$ & $18.7[20]$ & 2.11 & $(0.75,6.00)$ & 0.159 \\
\hline Injecting drug use & $3.8[6]$ & 3.9 [2] & $3.7[4]$ & 0.95 & $(0.17,5.37)$ & 0.955 \\
\hline
\end{tabular}


Table 4 Laboratory results comparisons between uncomplicated and complicated SAB

\begin{tabular}{|c|c|c|c|c|c|c|}
\hline \multirow[t]{2}{*}{ Laboratory Result } & \multirow{2}{*}{$\begin{array}{l}\text { Total } \\
\%[n=158]\end{array}$} & \multirow{2}{*}{$\begin{array}{l}\text { Uncomplicated } \\
\%[n=51]\end{array}$} & \multirow{2}{*}{$\begin{array}{l}\text { Complicated } \\
\%[n=107]\end{array}$} & \multicolumn{3}{|c|}{ Comparison $^{a}$} \\
\hline & & & & Crude OR & $95 \% \mathrm{Cl}$ & $p$-value \\
\hline \multicolumn{7}{|l|}{ Microbiological tests } \\
\hline PSSA & $18.4[29]$ & $17.6[9]$ & $18.7[20]$ & 1.07 & $(0.45,2.56)$ & 0.874 \\
\hline MSSA & $74.1[117]$ & $74.5[38]$ & $73.8[79]$ & 0.97 & $(0.45,2.07)$ & 0.928 \\
\hline nm-MRSA & $5.1[8]$ & $5.9[3]$ & $4.7[5]$ & 0.78 & $(0.18,3.42)$ & 0.746 \\
\hline MRSA & $2.5[4]$ & $2.0[1]$ & $2.8[3]$ & 1.44 & $(0.76,14.22)$ & 0.754 \\
\hline Poly-microbial & $10.8[17]$ & $17.6[9]$ & $7.5[8]$ & 0.38 & $(0.14,1.04)$ & 0.061 \\
\hline \multicolumn{7}{|l|}{ Blood tests } \\
\hline C-Reactive protein concentration median (IQR) & $144.0(141.0)[139]$ & $127.0(129.7)[48]$ & $160.0(145.6)[91]$ & 1.01 & $(1.00,1.01)$ & 0.007 \\
\hline Platelet cell count median (IQR) & $177.5(138.8)[150]$ & $190.0(126.5)[49]$ & $175.0(143.5)[101]$ & 1.00 & $(0.99,1.00)$ & 0.346 \\
\hline White cell count median (IQR) & $11.4(7.8)[150]$ & $10.0(6.2)[49]$ & $12.1(9.5)[101]$ & 1.07 & $(1.01,1.13)$ & 0.027 \\
\hline Lymphocyte cell count median (IQR) & $0.8(0.8)[150]$ & $0.8(0.85)[49]$ & $0.8(0.7)[101]$ & 0.85 & $(0.54,1.33)$ & 0.477 \\
\hline Neutrophil cell count median (IQR) & $9.1(6.6)[150]$ & $7.4(6.2)[49]$ & $9.8(7.5)[101]$ & 1.05 & $(0.98,1.13)$ & 0.146 \\
\hline C-reactive protein concentration over $161 \mathrm{mg} / \mathrm{L}$ & $40.3[56]$ & $22.9[11]$ & $49.5[45]$ & 3.29 & $(1.50,7.24)$ & 0.003 \\
\hline White blood cell count over $14.85 \times 10^{9} / \mathrm{L}$ & $30.7[46]$ & $16.3[8]$ & $37.6[38]$ & 3.09 & $(1.31,7.29)$ & 0.01 \\
\hline Neutrophil cell count over $9.25 \times 10^{9} / \mathrm{L}$ & $48.7[73]$ & $36.7[18]$ & $54.5[55]$ & 2.06 & $(1.02,4.15)$ & 0.043 \\
\hline
\end{tabular}

PSSA penicillin-sensitive $S$. aureus; MSSA methicillin-sensitive $S$. aureus; nm-MRSA non-multiple methicillin-resistant $S$. aureus; MRSA methicillin-resistant S. aureus; $I Q R$ interquartile range; $O R$ odds ratio; $\mathrm{Cl}$ Confidence interval

aUnivariable logistic regression model

outcomes [44]. However, it must be noted that patients with haemodialysis have been previously associated with increased risk for infective endocarditis [8] in all-cause bacteraemia infections.

Significantly, portals of entry were strongly associated with complications in SAB. In this study, an unknown portal of entry was the most common entry point of infection. The higher prevalence of unknown entry point in this study when compared to others, may be due to our definition of portal of entry rather than the infective focus that other studies have used $[3,45]$.

An unknown portal of entry was significantly associated with complications $\left(\mathrm{OR}_{\mathrm{adj}}\right.$ : 3.94, 95\% CI: [1.33, 11.62], $p=$ 0.013 ), as seen previously [46]. This may be due the increased risk of persistence due to the inability to identify the portal of entry and remove the infective focus, increasing the likelihood of $S$. aureus creating metastatic foci.

A portal of entry from an indwelling medical device (OR adj: 4.58, 95\% CI: $[1.14,18.35], p=0.025)$ was also significantly associated with complications. This may be due to the definition of complication which automatically categorises those with a prosthesis or cardiac device as a complicated case, regardless of whether the medical device is implicated in the infection [20]. Conversely, a portal of entry from a diabetic foot ulcer $\left(\mathrm{OR}_{\mathrm{adj}}\right.$ : 0.12 , 95\% CI: [0.02, 0.77], $p=0.012$ ) was inversely associated with complications. This may be due to increased management of diabetic foot ulcers but could also be due to the suppressed immune effects and reduced blood supply to the ulcer [47].

Table 5 Multiple logistic regression: potential risk factors for complications of S. aureus bacteraemia

\begin{tabular}{|c|c|c|c|c|c|}
\hline Covariates [ $n=139]$ & $\mathrm{OR}_{\mathrm{adj}}$ & $95 \% \mathrm{Cl}$ & $p$-value & $95 \% \mathrm{Cl}^{\mathrm{a}}$ & $p$-value \\
\hline Age & 1.03 & $(1.01,1.06)$ & 0.013 & $(1.01,1.06)$ & 0.014 \\
\hline Haemodialysis & 0.09 & $(0.01,0.97)$ & 0.047 & $(0.01,0.71)$ & 0.023 \\
\hline Nausea & 0.44 & $(0.18,1.07)$ & 0.070 & $(0.18,1.07)$ & 0.069 \\
\hline Diabetic foot ulcer entry point & 0.12 & $(0.02,0.62)$ & 0.012 & $(0.02,0.77)$ & 0.025 \\
\hline Unknown entry point & 3.94 & $(1.31,11.84)$ & 0.015 & $(1.33,11.62)$ & 0.013 \\
\hline Indwelling medical device entry point & 4.58 & $(1.21,17.26)$ & 0.025 & $(1.14,18.35)$ & 0.032 \\
\hline CRP over $161 \mathrm{mg} / \mathrm{L}$ on day of admission & 3.56 & $(1.29,9.79)$ & 0.014 & $(1.22,10.40)$ & 0.020 \\
\hline White blood cell count over $14.85 \times 10^{9}$ cells $/ L$ on day of admission & 2.93 & $(0.89,9.69)$ & 0.077 & $(0.93,9.28)$ & 0.067 \\
\hline
\end{tabular}

$O R_{\text {adj }}$ Adjusted Odds Ratio

Post estimation tests: Hosmer-Lemeshow's goodness of fit: chi2(8) $=5.12, p=0.744$, Area Under Curve $(\mathrm{AUC})=0.85$, Correctly Classified $=79.1 \%$

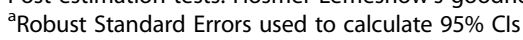


Investigation into predictive factors from routinely performed blood tests in a clinical setting showed three possible markers associated with complications in univariable analysis. Cut-off values showed high confidence intervals in white blood cell count and neutrophil cell count. This was due to the difference in numbers between the complicated and uncomplicated groups.

It was identified that a CRP concentration of over 161 $\mathrm{mg} / \mathrm{L}$ on the day of admission was significantly associated with complications $\left(\mathrm{OR}_{\mathrm{adj}}\right.$ : 3.56 ; $95 \% \mathrm{CI}$ : [1.22, 10.40], $p=0.020$ ). CRP is an acute phase protein of the pentraxin family. It is raised following an inflammatory injury and peaks the following day [48]. It aids in bacterial clearance by activating the classical pathway of the complement system through binding to Cq1 [49]. Interestingly, an inverse relationship has been observed in sepsis cases where a decreased expression of the HLA-
DR marker on monocytes was associated with persistently increased CRP concentration over time [19]. CRP has been investigated as a predictive risk factor in adult $\mathrm{SAB}$, with differing outcomes and study populations reflecting all different results. As seen in Table 6, prior studies are varied in terms of setting, population, outcome assessed, and potential cut-off value identified [3.0 $\mathrm{mg} / \mathrm{L}$ to $850 \mathrm{mg} / \mathrm{L}$ ]. Our study in comparison, is midrange in terms of study number, has the benefit of being a prospective collection, and attempts to include all complications. Conversely, our study is set in a community-onset $\mathrm{SAB}$ population, limiting the generalisability of the findings to all SAB cases.

CRP and full blood examinations are already routine blood immunoassays utilised in the diagnosis of infection and therefore have known parameters and remains stable when affected by delays into processing [60, 61].

Table 6 Summary of C-reactive protein association studies with bacteraemia

\begin{tabular}{|c|c|c|c|c|c|}
\hline $\begin{array}{l}\text { StudyFirst } \\
\text { Author }\end{array}$ & Setting & Population & Cut-off [mg/L] & Poor outcome & [Ref]. \\
\hline Horino & $\begin{array}{l}\text { Retrospective } \\
\text { Single centre } n=73\end{array}$ & $\begin{array}{l}\text { Adult } \\
\text { MSSA-SAB }\end{array}$ & $>30.0$ & Metastatic infection & {$[50]$} \\
\hline Holmes & $\begin{array}{l}\text { Prospective Multi- } \\
\text { centre } \\
n=222\end{array}$ & Adult SAB & $>250.0$ & 30-day Treatment failure & [32] \\
\hline Pravin & $\begin{array}{l}\text { Prospective } \\
\text { Cross-sectional Single } \\
\text { centre } \\
n=75\end{array}$ & $\begin{array}{l}\text { Neonates,All-causeSepsis } \\
\text { symptoms }\end{array}$ & $>30.0$ & Sepsis & {$[51]$} \\
\hline Bernstein & $\begin{array}{l}\text { Retrospective, Single } \\
\text { centre } \\
n=109\end{array}$ & $\begin{array}{l}\text { Paediatric } \boldsymbol{S} \text {. } \\
\text { aureusSeptic arthritis }\end{array}$ & $>13.7$ & MRSA Septic arthritis & [52] \\
\hline Bouchard & $\begin{array}{l}\text { Retrospective, Single } \\
\text { centren }=183\end{array}$ & $\begin{array}{l}\text { PaediatricAll-causeSeptic } \\
\text { arthritis }\end{array}$ & $<20.0$ & $\begin{array}{l}\text { Not reliable as a marker for clearance of } \\
\text { infection }\end{array}$ & [53] \\
\hline Tascini & $\begin{array}{l}\text { Retrospective } \\
\text { Multi-centre } \\
n=236\end{array}$ & $\begin{array}{l}\text { AdultAll-cause Infective } \\
\text { endocarditis }\end{array}$ & $>130.0>850.0$ & -S. aureus infective endocarditis-Death & [54] \\
\hline Molkanen & $\begin{array}{l}\text { Prospective } \\
\text { Multi-centre } \\
n=430\end{array}$ & Adult SAB & $\begin{array}{l}\text { Day } 4:>103.0 \text { Day } 14:> \\
\text { 61.0Day of diagnosis: }> \\
\text { 108.0Day } 14:>22.0\end{array}$ & -death-death-deep infection-deep infection & [55] \\
\hline Lin & $\begin{array}{l}\text { Retrospective } \\
\text { Single centre } \\
n=108\end{array}$ & $\begin{array}{l}\text { All ages,All-cause } \\
\text { Osteomyelitis }\end{array}$ & $\begin{array}{l}>5.0 \\
>8.0\end{array}$ & $\begin{array}{l}\text {-Prosthesis related-osteomyelitis recurrence } \\
\text {-Prosthesis unrelated-osteomyelitis recurrence }\end{array}$ & {$[56]$} \\
\hline Chiappini & $\begin{array}{l}\text { RetrospectiveSingle } \\
\text { centren }=121\end{array}$ & $\begin{array}{l}\text { PaediatricAll-causeAcute } \\
\text { haematogenous } \\
\text { osteomyelitis }\end{array}$ & $>10.0$ & $\begin{array}{l}\text { Complicated acute haematogenous } \\
\text { osteomyelitis }\end{array}$ & [57] \\
\hline Tang & $\begin{array}{l}\text { Retrospective } \\
\text { Single centre } \\
n=825\end{array}$ & $\begin{array}{l}\text { AdultAll-cause } \\
\text { bacteraemia }\end{array}$ & No cut-off & $\begin{array}{l}\text { Distinguishes positive and negative cultures, } \\
\text { Distinguishes between gram positive, negative } \\
\text { and candidaDistinguishes between species }\end{array}$ & {$[58]$} \\
\hline $\begin{array}{l}\text { Garcia del } \\
\text { Pozo }\end{array}$ & $\begin{array}{l}\text { Retrospective } \\
\text { Single centre } \\
n=116\end{array}$ & $\begin{array}{l}\text { AdultAll-causeLong } \\
\text { boneosteomyelitis }\end{array}$ & NA & Relapse recurrent osteomyelitis & [59] \\
\hline Botheras & $\begin{array}{l}\text { Prospective } \\
\text { Single centre } \\
n=158\end{array}$ & $\begin{array}{l}\text { Adult community-onset } \\
\text { SAB }\end{array}$ & $>161.0$ & Complicated SAB & \\
\hline
\end{tabular}


Therefore, these assays could quickly and efficiently be implemented into a management guideline. CRP could be an additional tool for resource poor healthcare settings to manage the condition by prioritising those with high CRP to have further diagnostic tests to assess for complications. Furthermore, given the increasing positive data on CRP as a predictive marker, it should be highly considered as an accessory marker for triaging patients. Future studies can help confirm the most appropriate cut-off value.

It also highlights the potential for other biomarkers to be predictive. Other studies have found several including, procalcitonin, IL-6, IL-10, IL-1 $\beta$, IL-17, TNFa and IFNy [62-67]. However, these markers are not routinely used in a clinical setting and to implement them into clinical practice would require significant additional resources.

There are several limitations to this study. Firstly, this study is from a single centre and the sample of patients is relatively modest. This limits the generalisability of the findings in other settings and potentially a loss of power to detect weaker associations that may exist. However, Pasco and colleagues demonstrated that the Geelong region population closely reflects the Australian population, through comparing the Barwon Statistical Division that represents Geelong and the national average, and showed the most divergent factor [Country of birth] differed by $9.5 \%$ [67]. Nonetheless, results of the study are promising, and we plan to extend this work to a larger study with multiple sites to further validate our model.

\section{Conclusion}

In this study, we aimed to identify potential predictive factors of complications in adult community-associated SAB. This included a quantified cut-off predictive marker of any potential blood markers already used in the clinical setting. It was identified that a history of haemodialysis was protective against complications in this cohort. The importance of the portal of entry in the outcome of SAB was observed. An unknown entry point and an entry point originating from an IMD were both significantly associated with complications, whereas a portal of entry from a DFU was protective against complications. Most importantly, we identified that a CRP over $161 \mathrm{mg} / \mathrm{L}$ on the day of admission was significantly associated with complicated disease and might offer a useful predictive tool to aid clinicians in the management of adult cases of community-associated SAB.

\section{Abbreviations}

S. aureus: Staphylococcus aureus; SAB: Staphylococcus aureus bacteraemia; CRP: C-reactive protein; UHG: University Hospital Geelong; EMR: Electronic medical records; CACl: Charlson age comorbidity index; HIV: Human immunodeficiency virus; SSTI: Skin and soft tissue infection; IMD: Indwelling medical device; IDU: Injecting drug use; PSSA: Penicillin-sensitive Staphylococcus aureus; MSSA: Methicillin-sensitive Staphylococcus aureus; nmMRSA: Non-multiple methicillin-resistant Staphylococcus aureus; MRSA: Methicillin-resistant Staphylococcus aureus; IQR: Interquartile range; ROC: Receiving operating curve; $\mathrm{Cl}$ : Confidence interval; OR: Odds ratio; $O R_{\text {adj: }}$ Adjusted odds ratio; AUC: Area under the curve; IL: Inter-leukin

\section{Acknowledgements}

We acknowledge Australian Clinical Laboratory Services [Formerly St. John of God Pathology Services] for their aid in identifying clinical cases of SAB.

\section{Authors' contributions}

CB collected, analysed, and wrote the manuscript. SB analysed the data, was a major contributor in writing and editing the manuscript. RC interpreted patient data regarding portal of entry of infection and complication status as well as editing of the manuscript. EA conceptualised the idea of the manuscript, interpreted patient data regarding portal of entry of infection and complication status as well as editing of the manuscript. All authors read and approved the final manuscript.

\section{Funding}

The authors declare no funding was involved in the production of this research.

\section{Availability of data and materials}

The datasets used and/or analysed during the current study are available from the corresponding author on reasonable request.

\section{Declarations}

\section{Ethics approval and consent to participate}

Exemption of ethical approval was given from the Barwon Health Research, Ethics, Governance, and Integrity unit (ratified by the Barwon Health HREC, Reference number: 16.33) and from Deakin University HREC (Reference number: 2017-217). Barwon Health Research, Ethics, Governance Integrity unit provided permission to access the data following ethical approval. Data was anonymised before use.

\section{Consent for publication}

Not applicable.

\section{Competing interests}

The authors declare that they have no competing interests.

\section{Author details}

${ }^{1}$ School of Medicine, IMPACT, the Institute for Mental and Physical Health and Clinical Translation, Deakin University, Geelong, Australia. ${ }^{2}$ School of Medicine, Faculty of Health, Deakin University, Geelong, Australia. ${ }^{3}$ Deakin Biostatistics Unit Faculty of Health, Deakin University, Geelong, Australia.

${ }^{4}$ Department of Infectious Diseases, Barwon Health, Geelong, Australia.

Received: 5 November 2020 Accepted: 7 March 2021

Published online: 01 April 2021

\section{References}

1. Rhee Y, Aroutcheva A, Hota B, Weinstein RA, Popovich KJ. Evolving epidemiology of Staphylococcus aureus bacteremia. Infect Control Hosp Epidemiol. 2015;36(12):1417-22. https://doi.org/10.1017/ice.2015.213.

2. Petersen ALA. Staphylococcus aureus bacteraemia cases in Denmark 2017. Denmark: Statens Serum Institut; 2018.

3. Coombs G, Daley D, Gottlieb T, Turnidge JD, Bell JM. Australian group on antimicrobial resistance: Sepsis outcome programs 2015 report. Sydney: Australian Commission on Safety and Quality in Health Care; 2017.

4. Bai AD, Showler A, Burry L, Steinberg M, Ricciuto DR, Fernandes T, Chiu A, Raybardhan S, Science M, Fernando E, Tomlinson G, Bell CM, Morris AM. Impact of infectious disease consultation on quality of care, mortality, and length of stay in Staphylococcus aureus bacteremia: results from a large multicenter cohort study. Clin Infect Dis. 2015;60(10):1451-61. https://doi. org/10.1093/cid/civ120. 
5. Kaasch AJ, Barlow G, Edgeworth JD, Fowler VG, Hellmich M, Hopkins S, et al. Staphylococcus aureus bloodstream infection: a pooled analysis of five prospective, observational studies. J Inf Secur. 2014;68(3):242-51.

6. Bayer AS, Ward JI, Ginzton LE, Shapiro SM. Evaluation of new clinical criteria for the diagnosis of infective endocarditis. Am J Med. 1994;96(3):211-9. https://doi.org/10.1016/0002-9343(94)90144-9.

7. Fowler VG Jr, Justice A, Moore C, Benjamin DK Jr, Woods CW, Campbell S, et al. Risk factors for hematogenous complications of intravascular catheterassociated Staphylococcus aureus bacteremia. Clin Infect Dis. 2005;40(5):695703. https://doi.org/10.1086/427806.

8. Mostaghim AS, Lo HYA, Khardori N. A retrospective epidemiologic study to define risk factors, microbiology, and clinical outcomes of infective endocarditis in a large tertiary-care teaching hospital. SAGE Open Med. 2017:5:2050312117741772.

9. Smit J, López-Cortés LE, Kaasch AJ, Søgaard M, Thomsen RW, Schønheyder $\mathrm{HC}$, Rodríguez-Baño J, Nielsen H. Gender differences in the outcome of community-acquired Staphylococcus aureus bacteraemia: a historical population-based cohort study. Clin Microbiol and Infect. 2017;23(1):27-32. https://doi.org/10.1016/j.cmi.2016.06.002.

10. Anderson DJ, Moehring RW, Sloane R, Schmader KE, Weber DJ, Fowler VG $\mathrm{Jr}$, et al. Bloodstream infections in community hospitals in the 21 st century: a multicenter cohort study. PLOS ONE. 2014;9(3):e91713.

11. Melzer M, Welch C. Thirty-day mortality in UK patients with communityonset and hospital-acquired meticillin-susceptible Staphylococcus aureus bacteraemia. J Hosp Infect. 2013;84(2):143-50. https://doi.org/10.1016/j.jhin.2 012.12.013.

12. Wehrhahn MC, Robinson JO, Pascoe EM, Coombs GW, Pearson JC, O'Brien FG, Tan HL, New D, Salvaris P, Salvaris R, Murray RJ. Illness severity in community-onset invasive Staphylococcus aureus infection and the presence of virulence genes. J Infect Dis. 2012;205(12):1840-8. https://doi.org/10.1093/ infdis/jis279.

13. Khatib R, Johnson LB, Fakih MG, Riederer K, Khosrovaneh A, Shamse Tabriz M, Sharma M, Saeed S. Persistence in Staphylococcus aureus bacteremia: incidence, characteristics of patients and outcome. Scand J Infect Dis. 2006: 38(1):7-14. https://doi.org/10.1080/00365540500372846.

14. Li Z, Feng J, Sun X. Is C-reactive protein a specific marker in melanoma? J Clin Oncol. 2015;33(31):3673-4. https://doi.org/10.1200/JCO.2015.62.2696.

15. Mei Z, Li H, Serdula MK, Flores-Ayala RC, Wang L, Liu J-M, et al. C-reactive protein increases with gestational age during pregnancy among Chinese women. Am J Hum Biol. 2016;28(4):574-9. https://doi.org/10.1002/ajhb.22837.

16. Sankaran G, Zacharia B, Roy A, Purayil SP. Current clinical and bacteriological profile of septic arthritis in young infants: a prospective study from a tertiary referral Centre. Eur J Orthop Surg Traumatol. 2018;28(4):573-8. https://doi. org/10.1007/s00590-018-2142-x

17. Povoa P, Almeida E, Moreira P, Fernandes A, Mealha R, Aragao A, et al. Creactive protein as an indicator of sepsis. Intensive Care Med. 1998;24.

18. Benoit JB, Frank DN, Bessesen MT. Genomic evolution of Staphylococcus aureus isolates colonizing the nares and progressing to bacteremia. PLOS ONE. 2018;13(5):e0195860.

19. Cajander S, Rasmussen G, Tina E, Magnuson A, Söderquist B, Källman J, et al. Dynamics of monocytic HLA-DR expression differs between bacterial etiologies during the course of bloodstream infection. PLOS ONE. 2018; 13(2):e0192883.

20. Liu C, Bayer A, Cosgrove SE, Daum RS, Fridkin SK, Gorwitz RJ, Kaplan SL, Karchmer AW, Levine DP, Murray BE, J Rybak M, Talan DA, Chambers HF, Infectious Diseases Society of America. Clinical practice guidelines by the Infectious Diseases Society of America for the treatment of methicillinresistant Staphylococcus aureus infections in adults and children. Clin Infect Dis. 2011;52(3):e18-55. https://doi.org/10.1093/cid/ciq146.

21. Charlson M, Szatrowski TP, Peterson J, Gold J. Validation of a combined comorbidity index. J Clin Epidemiol. 1994;47(11):1245-51. https://doi.org/1 0.1016/0895-4356(94)90129-5.

22. Tong SYC, Davis JS, Eichenberger E, Holland TL, Fowler VG Jr. Staphylococcus aureus infections: epidemiology, pathophysiology, clinical manifestations, and management. Clin Microbiol Rev. 2015;28(3):603-61. https://doi.org/1 0.1128/CMR.00134-14.

23. Le Moing V, Alla F, Doco-Lecompte T, Delahaye F, Piroth L, Chirouze C, et al. Staphylococcus aureus Bloodstream Infection and Endocarditis--A Prospective Cohort Study. PLOS ONE. 2015;10(5):e0127385.
24. Joost I, Kaasch A, Pausch C, Peyerl-Hoffmann G, Schneider C, Voll RE, et al. Staphylococcus aureus bacteremia in patients with rheumatoid arthritis data from the prospective INSTINCT cohort. J Inf Secur. 2017;74(6):575-84.

25. Hon KL, Tsang KYC, Kung JSC, Leung TF, Lam CWK, Wong CK. Clinical Signs, Staphylococcus and Atopic Eczema-Related Seromarkers. Molecules. 2017; 22:2.

26. McNicholas S, Fe Talento A, O'Gorman J, Hannan MM, Lynch M, Greene CM, et al. Reduced pro-inflammatory responses to Staphylococcus aureus bloodstream infection and low prevalence of enterotoxin genes in isolates from patients on haemodialysis. Eur J Clin Microbiol Infect Dis. 2017;36(1): 33-42. https://doi.org/10.1007/s10096-016-2767-9.

27. Smit J, Rieg SR, Wendel AF, Kern WV, Seifert H, Schønheyder HC, Kaasch AJ. Onset of symptoms, diagnostic confirmation, and occurrence of multiple infective foci in patients with Staphylococcus aureus bloodstream infection: a look into the order of events and potential clinical implications. Infection. 2018;46(5):651-8. https://doi.org/10.1007/s15010-018-1165-x.

28. Wehrhahn MC, Robinson JO, Pearson JC, O'Brien FG, Tan HL, Coombs GW, et al. Clinical and laboratory features of invasive community-onset methicillin-resistant Staphylococcus aureus infection: a prospective casecontrol study. Eur J Clin Microbiol Infect Dis. 2010;29(8):1025-33. https://doi. org/10.1007/s10096-010-0973-4.

29. Silva V, Almeida F, Carvalho JA, Castro AP, Ferreira E, Manageiro V, TejedorJunco MT, Caniça M, Igrejas G, Poeta P. Emergence of community-acquired methicillin-resistant Staphylococcus aureus EMRSA-15 clone as the predominant cause of diabetic foot ulcer infections in Portugal. Eur J Clin Microbiol Infect Dis. 2020;39(1):179-86. https://doi.org/10.1007/s10096-01903709-6.

30. StataCorp. Stata Statistical Software: Release 15. College Station, TX: StataCorp LLC.; 2017

31. Corp. I. IBM SPSS Statistics for Windows, Version 24.0. Armonk, NY: IBM Corp.: IBM Corp.; 2016

32. Holmes NE, Robinson JO, van Hal SJ, Munckhof WJ, Athan E, Korman TM, et al. Morbidity from in-hospital complications is greater than treatment failure in patients with Staphylococcus aureus bacteraemia. BMC Infectious Diseases. 2018;18(1):107-

33. Papakonstantinou PE, Samonis G, Andrianaki AM, Christofaki M, Dimopoulou D, Papadakis J, Gikas A, Kofteridis DP. Epidemiology, microbiological and clinical features, treatment, and outcomes of infective endocarditis in Crete, Greece. Infect Chemother. 2018;50(1):21-8. https://doi.org/10.3947/ic.2018. 50.1.21.

34. van Hal SJ, Jensen SO, Vaska VL, Espedido BA, Paterson DL, Gosbell IB. Predictors of mortality in Staphylococcus aureus bacteremia. Clin Microbiol Rev. 2012;25(2):362-86. https://doi.org/10.1128/CMR.05022-11.

35. Melzer M, Welch C. Does the presence of a urinary catheter predict severe sepsis in a bacteraemic cohort? J Hosp Infect. 2017;95(4):376-82. https://doi. org/10.1016/j.jhin.2017.01.003.

36. Chaudry MS, Gislason GH, Kamper A-L, Rix M, Dahl A, Østergaard L, et al. The impact of hemodialysis on mortality risk and cause of death in Staphylococcus aureus endocarditis. BMC Nephrol. 2018;19(1):216.

37. San-Juan R, Pérez-Montarelo D, Viedma E, Lalueza A, Fortún J, Loza E, Pujol M, Ardanuy C, Morales I, de Cueto M, Resino-Foz E, Morales-Cartagena MA, Fernández-Ruiz M, Rico A, Romero MP, Fernández de Mera M, López-Medrano F, Orellana MÁ, Aguado JM, Chaves F. Pathogen-related factors affecting outcome of catheter-related bacteremia due to methicillin-susceptible Staphylococcus aureus in a Spanish multicenter study. Eur J Clin Microbiol Infect Dis. 2017;36(10):1757-65. https://doi.org/10.1007/s10096-017-2989-5.

38. Subbaraju P, Rai S, Morakhia J, Midha G, Kamath A, Saravu K. Clinical microbiological characterization and risk factors of mortality in infective endocarditis from a tertiary care academic hospital in southern India. Indian Heart J. 2018;70(2):259-65. https://doi.org/10.1016/j.ihj.2017.08.007.

39. Kobayashi D, Yokota K, Takahashi O, Arioka H, Fukui T. A predictive rule for mortality of inpatients with Staphylococcus aureus bacteraemia: a classification and regression tree analysis. Eur J Intern Med. 2014;25(10):9148. https://doi.org/10.1016/j.ejim.2014.10.003.

40. Fowler VG Jr, Olsen MK, Corey G, et al. Clinical identifiers of complicated staphylococcus aureus bacteremia. Arch Intern Med. 2003;163(17):2066-72. https://doi.org/10.1001/archinte.163.17.2066.

41. Tubiana S, Duval X, Alla F, Selton-Suty C, Tattevin P, Delahaye F, et al. The VIRSTA score, a prediction score to estimate risk of infective endocarditis and determine priority for echocardiography in patients with Staphylococcus aureus bacteremia. J Inf Secur. 2016;72(5):544-53. 
42. Jorgensen SCJ, Lagnf AM, Bhatia S, Rybak MJ. A new simplified predictive model for mortality in methicillin-resistant Staphylococcus aureus bacteremia. Eur J Clin Microbiol Infect Dis. 2019;38(5):843-50. https://doi. org/10.1007/s10096-018-03464-0.

43. Aguilar-Company J, Pigrau C, Fernández-Hidalgo N, Rodríguez-Pardo D, Falcó $\mathrm{V}$, Lung M, Pellisé F, Almirante B. Native vertebral osteomyelitis in aged patients: distinctive features. An observational cohort study. Infection. 2018;46(5):679-86. https://doi.org/10.1007/s15010-018-1177-6.

44. El Zakhem A, Chaftari A-M, Bahu R, El Helou G, Shelburne S, Jiang Y, et al. Central line-associated bloodstream infections caused by Staphylococcus aureus in cancer patients: clinical outcome and management. Ann Med. 2014;46(3):163-8. https://doi.org/10.3109/07853890.2013.878513.

45. Qi R, Joo H-S, Sharma-Kuinkel B, Berlon NR, Park L, Fu C-L, et al. Increased in vitro phenol-soluble modulin production is associated with soft tissue infection source in clinical isolates of methicillin-susceptible Staphylococcus aureus. J Inf Secur. 2016;72(3):302-8.

46. Courjon J, Demonchy E, Degand N, Risso K, Ruimy R, Roger P-M. Patients with community-acquired bacteremia of unknown origin: clinical characteristics and usefulness of microbiological results for therapeutic issues: a single-center cohort study. Ann Clin Microbiol Antimicrob. 2017; 16(1):40.

47. Catrina S-B, Zheng X. Disturbed hypoxic responses as a pathogenic mechanism of diabetic foot ulcers. Diabetes Metab Res Rev. 2016;32(Suppl 1):179-85. https://doi.org/10.1002/dmrr.2742.

48. Peri $G$, Introna $M$, Corradi $D$, lacuitti $G$, Signorini $S$, Avanzini F, Pizzetti $F$, Maggioni AP, Moccetti T, Metra M, Cas LD, Ghezzi P, Sipe JD, Re G, Olivetti G, Mantovani A, Latini R. PTX3, a prototypical long pentraxin, is an early indicator of acute myocardial infarction in humans. Circulation. 2000;102(6): 636-41. https://doi.org/10.1161/01.CIR.102.6.636.

49. McGrath FDG, Brouwer MC, Arlaud GJ, Daha MR, Hack CE, Roos A. Evidence that complement protein C1q interacts with C-reactive protein through its globular head region. J Immunol. 2006;176(5):2950-7. https://doi.org/10.404 9/jimmunol.176.5.2950.

50. Horino T, Sato F, Hosaka Y, Hoshina T, Tamura K, Nakaharai K, Kato T, Nakazawa Y, Yoshida M, Hori S. Predictive factors for metastatic infection in patients with bacteremia caused by methicillin-sensitive Staphylococcus aureus. Am J Med Sci. 2015;349(1):24-8. https://doi.org/10.1097/MAJ. 0000000000000350 .

51. Pravin Charles MV, Kalaivani R, Venkatesh S, Kali A, Seetha KS. Evaluation of procalcitonin as a diagnostic marker in neonatal sepsis. Indian J Pathol Microbiol. 2018;61(1):81-4. https://doi.org/10.4103/IJPM.IJPM_820_16.

52. Bernstein DT, Haruno LS, Daram S, Dawson JR, Zhang W, Rosenfeld SB. Patient factors associated with methicillin-resistant Staphylococcus aureus septic arthritis in children. Orthopedics. 2018;41(2):e277-e82. https://doi. org/10.3928/01477447-20180213-04

53. Bouchard M, Shefelbine L, Bompadre V. C-Reactive Protein Level at Time of Discharge Is Not Predictive of Risk of Reoperation or Readmission in Children With Septic Arthritis. Front Surg. 2019;6(68).

54. Tascini C, Aimo A, Arzilli C, Sbrana F, Ripoli A, Ghiadoni L, Bertone C, Passino C, Attanasio V, Sozio E, Taddei E, Murri R, Fantoni M, Paciosi F, Francisci D, Pasticci MB, Pallotto C, di Caprio G, Carozza A, Maffei S, Emdin M. Procalcitonin, white blood cell count and C-reactive protein as predictors of S. aureus infection and mortality in infective endocarditis. Int J Cardiol. 2020; 301:190-4. https://doi.org/10.1016/j.ijcard.2019.08.013.

55. Mölkänen $T$, Ruotsalainen $E$, Rintala EM, Järvinen A. Predictive value of Creactive protein (CRP) in identifying fatal outcome and deep infections in Staphylococcus aureus bacteremia. PLoS One. 2016;11(5):e0155644. https:// doi.org/10.1371/journal.pone.0155644.

56. Lin Z, Vasudevan A, Tambyah PA. Use of erythrocyte sedimentation rate and C-reactive protein to predict osteomyelitis recurrence. J Orthop Surg (Hong Kong). 2016;24(1):77-83. https://doi.org/10.1177/230949901602400118.

57. Chiappini E, Camposampiero C, Lazzeri S, Indolfi G, De Martino M, Galli L. Epidemiology and Management of Acute Haematogenous Osteomyelitis in a Tertiary Paediatric Center. Int J Environ Res Public Health. 2017;14(5).

58. Tang A, Caballero AR, Bierdeman MA, Marquart ME, Foster TJ, Monk IR, et al. Staphylococcus aureus Superantigen-Like Protein SSL1: A Toxic Protease. Pathogens. 2019;8(1).

59. Garcia Del Pozo E, Collazos J, Carton JA, Camporro D, Asensi V. Factors predictive of relapse in adult bacterial osteomyelitis of long bones. BMC Infect Dis. 2018;18(1):635-.
60. Aziz N, Fahey JL, Detels R, Butch AW. Analytical performance of a highly sensitive C-reactive protein-based immunoassay and the effects of laboratory variables on levels of protein in blood. Clin Diagn Lab Immunol. 2003;10(4):652-7. https://doi.org/10.1128/CDLI.10.4.652-657.2003.

61. Ledue TB, Rifai N. Preanalytic and analytic sources of variations in C-reactive protein measurement: implications for cardiovascular disease risk assessment. Clin Chem. 2003;49(8):1258-71. https://doi.org/10.1373/49.8.12 58.

62. Yan ST, Sun LC, Jia HB, Gao W, Yang JP, Zhang GQ. Procalcitonin levels in bloodstream infections caused by different sources and species of bacteria. Am J Emerg Med. 2017;35(4):579-83. https://doi.org/10.1016/j.ajem.2016.12. 017.

63. Dey I, Bishayi B. Role of Th17 and Treg cells in septic arthritis and the impact of the Th17/Treg -derived cytokines in the pathogenesis of S. aureus induced septic arthritis in mice. Microb Pathog. 2017;113(Supplement C): 248-64.

64. Leech JM, Lacey KA, Mulcahy ME, Medina E, McLoughlin RM. IL-10 plays opposing roles during Staphylococcus aureus systemic and localized infections. J Immunol. 2017;198(6):2352-65. https://doi.org/10.4049/ jimmunol.1601018.

65. Alves De Souza C, Queiroz Alves De Souza A, Queiroz Alves De Souza MDS, Dias Leite JA, Silva De Morais M, Barem Rabenhorst SH. A link between osteomyelitis and ILIRN and IL1B polymorphisms-a study in patients from Northeast Brazil. Acta Orthop. 2017;88(5):556-61. https://doi.org/10.1080/174 53674.2017.1348439.

66. Friebe A, Volk HD. Stability of tumor necrosis factor alpha, interleukin 6, and interleukin 8 in blood samples of patients with systemic immune activation. Arch Pathol Lab Med. 2008;132(11):1802-6. https://doi.org/10.5858/132.11.1 802.

67. Parker D, Planet PJ, Soong G, Narechania A, Prince A. Induction of type I interferon signaling determines the relative pathogenicity of Staphylococcus aureus strains. PLOS Pathog. 2014;10(2):e1003951.

68. Pasco JA, Nicholson GC, Kotowicz MA. Cohort profile: Geelong osteoporosis study. Int J Epidemiol. 2012;41(6):1565-75. https://doi.org/10.1093/ije/dyr148.

\section{Publisher's Note}

Springer Nature remains neutral with regard to jurisdictional claims in published maps and institutional affiliations.

\section{Ready to submit your research? Choose BMC and benefit from:}

- fast, convenient online submission

- thorough peer review by experienced researchers in your field

- rapid publication on acceptance

- support for research data, including large and complex data types

- gold Open Access which fosters wider collaboration and increased citations

- maximum visibility for your research: over $100 \mathrm{M}$ website views per year

At BMC, research is always in progress.

Learn more biomedcentral.com/submissions 